\title{
Kewajiban Negara dalam Proses Ratifikasi Perjanjian Internasional: Memastikan Keselarasan dengan Konstitusi dan Mentransformasikan ke Hukum Nasional
}

\author{
Hikmahanto Juwana \\ Fakultas Hukum Universitas Indonesia \\ hikmahanto@yahoo.com
}

\begin{abstract}
This article seeks to discuss responsibilities the state should take into consideration in the ratification process of international agreements. Such a discussion is needed due to many international agreements that Indonesia has participated in, either by signing orby ratification in the forms of legislations or presidential decrees. It is concluded from the article that there are two responsibilities have to be taken in the process of ratification; first, ensuring the compliance of any international agreements with the Constitution. Not only do the Constitution functions as agrand norm in the hierarchy of Indonesian law, the compliance with the Constitution is also urgent to ensure the uniformity of government perception when dealing with the international agreements with the people's perception and to avoidany vested interests from other countries against the sovereignty of Indonesia considering that the international agreements might have been used as political instruments by one country over the others. Second, the responsibility to transform the international agreements into the national laws. The transformation, particularly of the international agreements with law making treaties, is essential to change any regulations of certain countries into legislations in other countries.
\end{abstract}

Keywords: International agreements; national law; ratification; Constitution. 


\section{Abstrak}

Artikel ini membahas kewajiban apa saja yang harus dilakukan negara dalam proses ratifikasi perjanjian internasional. Pembahasan ini diperlukan karena telah banyak perjanjian internasional yang diikuti oleh Indonesia, baik melalui penandatanganan maupun ratifikasi dalam bentuk pengesahannya berupa undang-undang atau peraturan presiden. Artikel ini menyimpulkan ada dua kewajiban yang harus dilakukan dalam proses ratifikasi, yaitu, pertama, memastikan keselarasan perjanjian internasional dengan Konstitusi. Selain karena Konstitusi merupakan norma tertinggi dalam hirarki peraturan perundang-undangan Indonesia, keselaran dengan Konstitusi juga diperlukan untuk memastikan kesamaan persepsi pemerintah ketika hendak mengikuti suatu perjanjian internasional dengan persepsi rakyat dan memastikan terhindarnya intervensi terselubung yang dilakukan oleh negara lain terhadap kedaulatan negara mengingat perjanjian internasional kerap dijadikan instrumen politik oleh satu negara terhadap negara lain. Kedua, kewajiban mentransformasikan perjanjian internasional ke dalam hukum nasional. Kewajiban transformasi ini, terutama pada perjanjian internasional yang memiliki substansi "law making treaties”, dilakukan untuk mengubah ketentuan yang berlaku dalam suatu negara, dalam hal ini berarti perlu penerjemahan ketentuan dalam perjanjian internasional ke dalam peraturan perundang-undangan suatu negara.

Kata Kunci: perjanjian internasional; hukum nasional; ratifikasi; Konstitusi.

\section{A. Pendahuluan}

Artikel ini membahas kewajiban apa saja yang harus dilakukan oleh negara dalam proses ratifikasi perjanjian internasional. Pembahasan ini diperlukan karena, pertama, sejak merdeka, telah banyak perjanjian internasional yang diikuti oleh Indonesia. Keikutsertaan (accede) ${ }^{1}$ Indonesia dalam perjanjian internasional ada yang dilakukan dengan penandatanganan dan ada pula yang melalui proses ratifikasi yang bentuk pengesahannya berupa Undang-undang (UU) atau Peraturan

1 Ikut serta (accession) dan ratifikasi (ratification) merupakan dua istilah yang berbeda dalam hukum internasional. Ikut serta terkait dengan proses untuk mengikuti suatu perjanjian internasional. Sementara ratifikasi adalah suatu proses di mana dibutuhkan pengesahan oleh negara yang akan ikut serta. 
Presiden (Perpres). Untuk menentukan mana ratifikasi yang didasarkan pada UU dan mana yang didasarkan pada Perpres telah mendapat pengaturan dalam UU Nomor 24 Tahun 2000 tentang Perjanjian Internasional (UU 24 Tahun 2000) dan Putusan Mahkamah Konstitusi (MK) Nomor 13/PUU-XVI/ 2018.

Kedua, dalam hirarki hukum nasional, sesungguhnya tidak dijumpai Perjanjian Internasional sebagai bagian dari jenis peraturan perundang-undangan. Secara hirarkis, sebagaimana diatur dalam UU Nomor 12 Tahun 2011 tentang Pembentukan Peraturan Perundangundangan (UU 12 Tahun 2011), peraturan perundang-undangan di Indonesia terdiri dari Undang-Undang Dasar Negara Republik Indonesia Tahun 1945, Ketetapan Majelis Permusyawaratan Rakyat, UU/ Peraturan Pemerintah Pengganti UU, Peraturan Pemerintah, Perpres, Peraturan Daerah Provinsi, dan Peraturan Daerah Kabupaten/ Kota. ${ }^{2}$ UU tidak menyebutkan bagaimana sebenarnya kedudukan dari perjanjian internasional yang telah diikuti oleh Indonesia baik melalui proses ratifikasi ataupun tidak. Meskipun demikian, dalam literatur tentang Pengantar Ilmu Hukum atau Pengantar Hukum Indonesia disebutkan salah satu sumber hukum di Indonesia adalah perjanjian internasional yang telah diikuti. ${ }^{3}$

Struktur peraturan perundang-undangan di Indonesia menegaskan Undang-Undang Dasar (UUD) atau Konstitusi merupakan jenis peraturan perundang-undangan yang secara hirarkis tertinggi. Oleh karena itu, semua peraturan perundang-undangan harus selaras atau sinkron dengan Konstitusi. Dari sejumlah perjanjian internasional yang telah diikuti oleh Indonesia, menjadi pertanyaan, apakah berbagai perjanjian internasional tersebut telah melalui proses penyelarasan dengan Konstitusi. Artikel ini hendak mengkaji hal-hal yang terkait dengan perlunya memastikan keselarasan perjanjian internasional

2 Pasal 7 Ayat (1) UU 12 Tahun 2011.

3 Lihat: L.J. van Apeldoorn, Pengantar Ilmu Hukum (Jakarta: Noor Komala, 1962), hlm. 131-133. Memang bisa diperdebatkan apakah sebagai sumber hukum di Indonesia, hakim dapat menggunakan perjanjian internasional pada bentuk aslinya atau hakim hanya terikat bila substansi perjanjian internasional tersebut telah ditransformasikan ke dalam peraturan perundang-undangan nasional. 
dengan UUD.

Ketiga, proses ratifikasi perjanjian internasional sesungguhnya memerlukan transformasi ke dalam hukum nasional. ${ }^{4}$ Dalam proses transformasi ini, penting dibahas, bagaimana negara menerjemahkan isi perjanjian internasional ke dalam hukum nasional, karena biasanya akan diikuti dengan perubahan ketentuan yang berlaku dalam suatu negara. Artikel ini dengan membedakan substansi yang diatur dalam perjanjian internasional, akan membahas bagaimana transformasi ini dilakukan.

Dalam membahas dan mendiskusikan kewajiban negara dalam proses ratifikasi perjanjian internasional, artikel ini mengawalinya dengan uraian mengapa perjanjian internasional yang akan diikuti oleh Indonesia perlu dipastikan keselarasannya dengan UUD. Berikutnya dibahas tentang bagaimana praktik Indonesia ketika hendak mengikuti suatu perjanjian internasional. Selanjutnya akan dilakukan pembahasan terhadap kemungkinan instrumen ratifikasi (instrument of ratification) baik berupa UU maupun Perpres diuji materi di Mahkamah Konstitusi (MK) atau Mahkamah Agung (MA) serta implikasinya bila dibatalkan. Terakhir akan diuraikan apa yang harus dilakukan oleh Indonesia ke depan.

\section{B. Kewajiban Memastikan Keselarasan dengan Konstitusi}

Ada paling tidak tiga alasan mengapa perjanjian internasional yang hendak diikuti oleh Indonesia harus dipastikan keselarasannya dengan UUD. Pertama, mengingat Undang-undang Dasar 1945 merupakan

4 Dalam artikel sebelumnya, penulis mengatakan bahwa tidak ada kaitan antara instrumen untuk meratifikasi suatu perjanjian internasional dengan peraturan perundang-udangan yang mentransformasikan ketentuan dalam perjanjian internasional. Instrumen untuk meratifikasi dalam UU Perjanjian Internasional ditentukan dapat berbentuk UU maupun Peraturan Presiden sesuai dengan kriteria yang ditentukan. Instrumen ini yang harus disampaikan ke tempat yang menerima deposit untuk menandakan keikutsertaan Indonesia. Namun, instrumen ini tidak dapat digunakan untuk keberlakuan perjanjian internasional tersebut, sepanjang ketentuan yang ada belum diterjemahkan ke dalam hukum nasional. Lihat: Hikmahanto Juwana, "Catatan atas Masalah Aktual dalam Perjanjian Internasional", Jurnal Hukum Internasional, 5, 3 (2008), hlm. 445. 
norma tertinggi dalam hirarki peraturan perundang-undangan Indonesia. Dalam Pasal 7 ayat (1) UU 12 Tahun 2011 disebutkan bahwa jenis dan hirarki peraturan perundang-undangan adalah UUD; TAP MPR, UU/Peraturan Pemerintah Pengganti UU; Peraturan Pemerintah; Perpres; dan Peraturan daerah. Dalam hirarki tersebut tidak disebutkan kedudukan dari perjanjian internasional yang telah diikuti oleh Indonesia baik melalui proses ratifikasi ataupun tidak.

Kedua, memastikan keselarasan antara perjanjian internasional yang akan diikuti dengan Konstitusi penting untuk memastikan kesamaan persepsi pemerintah ketika hendak mengikuti suatu perjanjian internasional dengan persepsi rakyat. Penyamaan persepsi antara pemerintah dengan rakyat dibutuhkan karena pemerintah dan rakyat difiksikan telah membuat kesepakatan yang dituangkan dalam Konstitusi. Oleh karenanya perjanjian internasional harus dipastikan sesuai dan selaras dengan Konstitusi.

Perlu dipahami Konstitusi harus difiksikan sebagai kesepakatan antara rakyat dengan pemerintah. Rakyat sebagai pihak yang memiliki kedaulatan tetapi sekaligus pihak yang diperintah. Sementara pemerintah dalam pengertian yang luas adalah pihak yang mendapat amanah menjalankan kedaulatan sekaligus sebagai pihak yang memerintah rakyat. Konstitusi adalah instrumen yang memastikan agar pemerintah menjalankan kewajibannya kepada rakyat, paling tidak berupa usaha mensejahterakan, mencerdaskan, dan melindungi. Rakyat memiliki berbagai mekanisme untuk memastikan agar pemerintah menjalankan kesepakatan yang dibuat dengan rakyat. Di alam demokrasi, rakyat bisa mengawasi melalui pemilihan umum, media, bahkan melakukan uji materi atas produk peraturan perundangundangan yang dikeluarkan oleh pemerintah.

Dalamkonteks demikian, ketika Presiden dan Dewan Perwakilan Rakyat (DPR) membuat UU maka persepsi kedua lembaga ini yang dituangkan dalam materi UU dapat diuji oleh rakyat. Rakyat dapat mengajukan uji materi (judicial review) atas ketentuan dalam UU ke MK. Hal yang sama juga berlaku terhadap peraturan perundangundangan yang berada di bawah UU yang diajukan ke MA.

Terakhir, memastikan keselarasan suatu perjanjian internasional 
yang hendak diikuti oleh Indonesia bertujuan memastikan terhindarnya intervensi terselubung yang dilakukan oleh negara lain terhadap kedaulatan, termasuk kedaulatan hukum Indonesia. Hal ini penting mengingat perjanjian internasional kerap dijadikan sebagai instrumen politik oleh satu negara terhadap negara lain. ${ }^{5}$

\section{Praktik Keikutsertaan Indonesia dalam Perjanjian Internasional}

UU 24 Tahun 2000 telah menentukan prosedur pengesahan atau ratifikasi dari suatu perjanjian internasional yang akan diikuti oleh Indonesia. Uraian mengenai hal ini tertuang dalam Pasal 10 dan 11 UU 24 Tahun 2000, bahwa pengesahan dilakukan dengan UU atau Perpres akan bergantung pada materi perjanjian internasional. ${ }^{\circ}$ Belakangan, MK dalam putusannya Nomor 13/PUU-XVI/2018 memperluas cakupan perjanjian internasional yang harus disahkan dengan UU, yaitu terhadap hal-hal yang "menimbulkan akibat yang luas dan mendasar bagi kehidupan rakyat yang terkait dengan beban keuangan negara dan/atau mengharuskan perubahan atau pembentukan undang-undang”.

Dalam praktiknya sejauh ini, ada tiga praktik ketika Indonesia hendak mengikuti suatu perjanjian internasional bila dikaitkan dengan proses perlu atau tidaknya ratifikasi. Pertama, tidak dilakukannya proses ratifikasi perjanjian internasional yang sekalipun memenuhi kriteria yang seharusnya diratifikasi dengan UU

5 Hikmahanto Juwana, "Hukum Internasional Sebagai Instrumen Politik: Beberapa Pengalaman Indonesia Sebagai Studi Kasus," Jurnal Hukum Internasional, 1, 1 (2003): 78-100.

6 Berdasarkan Pasal 10 UU 24 Tahun 2000, katagori perjanjian internasional yang pengesahannya dilakukan dengan UU adalah apabila berkenaan dengan: a. masalah politik, perdamaian, pertahanan, dan keamanan negara; b. perubahan wilayah atau penetapan batas wilayah negara Republik Indonesia; c. kedaulatan atau hak berdaulat negara; $d$. hak asasi manusia dan lingkungan hidup; e. pembentukan kaidah hukum baru; f. pinjaman dan/ atau hibah luar negeri. Sementara Pasal 11 menentukan bahwa pengesahan perjanjian internasional yang materinya tidak termasuk materi sebagaimana dimaksud Pasal 10, dilakukan dengan keputusan presiden (sekarang: peraturan presiden). 
berdasarkan UU 24 Tahun 2000 disebabkan perjanjian internasional tersebut tidak mensyaratkan instrumen ratifikasi. Perjanjian internasional ini bahkan menggunakan istilah yang seolah-olah bukan suatu perjanjian internasional, seperti letter of intent (LoI) atau memorandum of understanding (MoU). Sebagai contoh adalah LoI yang ditandatangani oleh pemerintah dengan International Monetary Fund (IMF) ketika Indonesia menghadapi krisis moneter dan ekonomi. ${ }^{7}$ Padahal substansi yang diatur berpotensi melanggar kedaulatan atau hak berdaulat negara mengingat di dalam LoI ada kebijakan ataupun peraturan perundang-undangan yang diminta namun tidak dilakukan proses pengesahan oleh DPR. LoI mewajibkan Indonesia untuk menerbitkan amandemen terhadap UU Kepailitan dan UU Persaingan Usaha. ${ }^{8}$

Contoh lain adalah $\mathrm{MoU}$ antara Pemerintah Indonesia dengan Malaysia terkait dengan Rekrutmen dan Penempatan Pekerja Domestik (Memorandum of Understanding between the Government of the Republic of Indonesia and the Government of Malaysia on the Recruitment and Placement of Indonesian Domestic Workers) tahun 2006. ${ }^{\circ}$ Dilihat dari substansinya, MoU ini penting untuk mendapatkan pengesahan dari DPR, mengingat aspek perlindungan warga negara yang harus dilakukan oleh pemerintah. Hanya saja karena tidak ada ketentuan yang mengatur diperlukannya instrumen ratifikasi, dan pemerintah sebagai penentu perlu tidaknya diratifikasi tidak mengharuskannya, maka MoU ini tidak diratifikasi.

Kedua, proses ratifikasi oleh pemerintah terhadap perjanjian internasional yang sebenarnya tidak secara eksplisit mensyaratkan

7 Bentuk LoI antara Pemerintah Indonesia dengan IMF tidak dalam format suatu perjanjian internasional melainkan dalam bentuk surat Pemerintah Indonesia kepada IMF yang berisi tentang apa yang dijanjikan oleh Pemerintah Indonesia. Tindakan yang harus dilakukan oleh Pemerintah Indonesia bukan merupakan rencana pemerintah semata, melainkan berdasarkan diskusi dengan pembahasan dengan IMF.

8 Letter of Intent of the Government of Indonesia to International Monetary Fund (October 31, 1997), http:/ /www.imf.org/external/np/loi/ 103197.HTM, diakses 4/5/2011.

9 Dokumendapatdiaksesdihttp:/ / pstalker.com/ilo/ resources/Malaysia\%20 Indonesia\%20MOU\%20\&\%20Appendix\%20A-B.pdf, diakses 17/5/2011. 
dokumen ratifikasi. Sebagai contoh adalah perjanjian bilateral di bidang pertahanan, salah satunya perjanjian bilateral antara pemerintah Indonesia dan pemerintah Australia yang mengikatkan diri pada Agreement Between the Republic of Indonesia and Australia on the Framework for Security Cooperation ${ }^{10}$ tertanggal 13 Nopember 2006. Berdasarkan Pasal 10 ayat (1) ditentukan bahwa, "The Agreement shall enter into force on the date of receipt of the last notification by which the Parties notify each other that their internal requirements for the entry into force of this Agreement have been fulfilled." Proses ratifikasi dilakukan atas dasar kata-kata "that their internal requirements for the entry into force." Ratifikasi atas perjanjian internasional ini dilakukan dengan UU. ${ }^{11}$

Demikian pula perjanjian kerjasama di bidang ekonomi antara Indonesia dengan negara lain. Sebagai contoh dalam Agreement between Japan and the Republic of Indonesia for an Economic Partnership ${ }^{12}$ tertanggal 20 Agustus 2007. Dalam Pasal 153 disebutkan bahwa, "This Agreement shall enter into force on the thirtieth day after the date on which the Governments of the Parties exchange diplomatic notes informing each other that their respective legal procedures necessary for entry into force of this Agreement have been completed." Kata-kata "their respective legal procedures necessary for entry into force" ditafsirkan oleh pemerintah Indonesia sebagai adanya persyaratan ratifikasi. Ratifikasi atas perjanjian internasional ini dilakukan dengan Perpres. ${ }^{13}$

Meski telah ditentukan dalam UU 24 Tahun 2000, keputusan apakah pengesahan ratifikasi dilakukan melalui DPR atau cukup di

10 Dokumen dapat diakses di http:/ / www.dfat.gov.au/geo/indonesia/indaus-sec06.html, diakses 11/5/2011.

11 Peraturan Presiden Nomor 36 Tahun 2008 tentang Pengesahan Agreement Between the Republic of Indonesia and Japan for An Economic Partnership (Persetujuan antara Republik Indonesia dan Jepang mengenai suatu Kemitraan Ekonomi).

12 Dokumen dapat diakses di http://www.mofa.go.jp/region/asia-paci/ indonesia/epa0708/agreement.pdf, diakses 11/5/2011.

13 UU Nomor 47 Tahun 2007 tentang Pengesahan Perjanjian antara Republik Indonesia dan Australia tentang Kerangka Kerja Sama Keamanan (Agreement between the Republic of Indonesia and Australia on the Framework for Security Cooperation). 
tingkat Presiden tetap berada di tangan pemerintah. Dengan demikian, pemerintah yang menentukan apakah ratifikasi suatu perjanjian internasional perlu mendapat pengesahan dari DPR atau cukup Presiden. ${ }^{14}$

Ketiga, proses ratifikasi perjanjian internasional yang mensyaratkan instrumen ratifikasi agar dapat diberlakukan di Indonesia. Perjanjian internasional jenis ini secara tegas mensyaratkan instrumen ratifikasi. Instrumen ini harus diserahkan (deposit) ke negara yang telah ditunjuk atau organisasi internasional sebagai penyimpan (depository). Salah satu contoh adalah International Covenant on Civil and Political Rights (ICCPR). ${ }^{15}$ Dalam Pasal 49 ayat (2) ditentukan bahwa, "For each State ratifying the present Covenant or acceding to it after the deposit of the thirty-fifth instrument of ratification or instrument of accession, the present Covenant shall enter into force three months after the date of the deposit of its own instrument of ratification or instrument of accession." Indonesia pada tahun 2005 telah ikut sebagai peserta ICCPR dengan menyampaikan instrumen ratifikasi. ${ }^{16}$

14 Dalam putusannya Nomor 13/PUU-XVI/2018, Mahkamah Konstitusi menyatakan bahwa ketentuan Pasal 10 UU 24 Tahun 2000 "Pengesahan perjanjian internasional dilakukan dengan undang-undang apabila berkenaan dengan: (a) masalah politik, perdamaian, pertahanan, dan keamanan negara; (b) perubahan wilayah atau penetapan batas wilayah negara Republik Indonesia; (c) kedaulatan atau hak berdaulat negara; (d) hak asasi manusia dan lingkungan hidup; (e) pembentukan kaidah hukum baru; (f) pinjaman dan/atau hibah luar negeri” tidak mempunyai kekuatan hukum mengikat secara bersyarat sepanjang ditafsirkan bahwa hanya jenis-jenis perjanjian internasional tersebut saja yang mempersyaratkan persetujuan DPR. Menurut MK, pengesahan perjanjian internasional, selain berkenaan dengan hal-hal tersebut, juga diperlukan dalam hal "menimbulkan akibat yang luas dan mendasar bagi kehidupan rakyat yang terkait dengan beban keuangan negara dan/atau mengharuskan perubahan atau pembentukan undang-undang", sebagaimana dimaksud dalam Pasal 11 ayat (2) UUD 1945.

15 Dokumen dapat diakses di http://www.austlii.edu.au/au/other/dfat/ treaties/1980/23.html, diakses 11/5/2011.

16 Instrumen ratifikasi yang disampaikan berupa UU yang mengesahkan ICCPR yaitu Undang-undang Nomor 12 Tahun 2005, Undang-undang Nomor 12 Tahun 2005 tentang Pengesahan International Covenant on Civil and Political Rights (Kovenan International tentang Hak-hak Sipil dan Politik). 
Dari ketiga praktik ini, tampaknya tidak ada suatu proses yang dilalui untuk memastikan keselarasan antara perjanjian internasional dengan UUD. Dalam pengertian demikian tidak ada proses untuk mencermati apakah perjanjian internasional tertentu berpotensi untuk bertentangan dengan UUD atau tidak. Benturan antara norma dalam perjanjian internasional dengan UUD baru diketahui pasca perjanjian internasional diikuti.

Bagi perjanjian internasional yang diikuti oleh Indonesia di mana proses pengesahan tidak dilakukan, maka tidak ada kajian apa pun terkait dengan perjanjian internasional tersebut. Termasuk dalam katagori ini adalah LoI antara Indonesia dengan IMF atau MoU antara Indonesia dengan Malaysia. Kedua bentuk perjanjian internasional demikian setelah ditandatangani langsung dinyatakan berlaku.

Pada pengesahan perjanjian internasional yang mensyarakatkan proses ratifikasi, juga terdapat perbedaan bagaimana pengesahan tersebut dilakukan. Dalam hal pengesahan dilakukan dengan UU, diharuskan ada naskah akademik, sedangkan pengesahan yang dilakukan dengan Perpres tidak terdapat naskah akademik. Hanya saja dalam naskah akademik yang menyertai UU pengesahan tidak ada pembahasan terkait dengan keselarasan antara perjanjian internasional yang akan diikuti dengan UUD. Naskah akademik yang dibuat biasanya sangat sederhana, lebih berisi tentang alasan mengapa perjanjian internasional perlu diikuti oleh Indonesia dan ringkasan materi dari perjanjian internasional.

Bila dicermati dalam UU pengesahan pun tidak ada indikasi bahwa perjanjian internasional yang diikuti telah dipastikan tidak berbenturan dengan norma UUD. Dalam UU pengesahan, sebagaimana layaknya UU, di dalam bagian penjelasan umum tidak ada pembahasan apakah perjanjian internasional yang akan diikuti telah selaras dengan UUD. Dalam bagian penjelasan umum hanya dijelaskan substansi dari perjanjian internasional dalam bentuk ringkas. Bila instrumen ratifikasi dibuat dengan Perpres, maka tidak ada naskah akademik. Bahkan bagian penjelasan pun tidak ada. Ini berarti perjanjian internasional yang diratifikasi melalui Perpres pun sama 
sekali tidak ada pembahasan tentang keselarasan dengan UUD.

Bagi perjanjian internasional yang harus melalui proses ratifikasi maka instrumen untuk meratifikasi berpotensi untuk diujimaterikan ke MK atau ke MA. Potensi ini didasarkan pada ketentuan yang diatur dalam Konstitusi dan UU Kekuasaan Kehakiman, bahwa MK berwenang mengadili pada tingkat pertama dan terakhir yang putusannya bersifat final untuk menguji undang-undang terhadap UUD, ${ }^{17}$ dan MA Mahkamah Agung berwenang menguji peraturan perundang-undangan di bawah undang-undang terhadap undangundang. ${ }^{18}$ Mengingat instrumen ratifikasi berbentuk UU atau Perpres, maka UU atau Perpres tersebut tentu bisa diajukan ke MK atau MA untuk dilakukan uji materi.

Ada dua kemungkinan yang dapat diputus oleh MK atau MA terkait dengan instrumen ratifikasi yang hendak dibatalkan. Pertama adalah MKatau MA menyatakan diritidakberwenang(nietontvantkelijk verklaard) untuk melakukan pembatalan karena instrumen ratifikasi berbentuk beschikking. Hal ini didasarkan pada kenyataan bahwa UU atau Perpres dapat berupa tindakan pemerintah yang bersifat satu kali (einmalig) dan konkret sehingga berupa penetapan (beschikking) atau bermuatan pengaturan (regelling). Untuk diketahui, instrumen pengesahan baik berupa UU atau Perpres hanya memuat dua pasal. ${ }^{19}$

17 Pasal 24 C Ayat (1) UUD 1945: "Mahkamah Konstitusi berwenang mengadili pada tingkat pertama dan terakhir yang putusannya bersifat final untuk menguji undang-undang terhadap Undang-Undang Dasar...”. Pasal 29 ayat (1) huruf (a) UU Nomor 48 Tahun 2009 tentang Kekuasaan Kehakiman (UU 48 Tahun 2009): "Mahkamah Konstitusi berwenang mengadili pada tingkat pertama dan terakhir yang putusannya bersifat final untuk menguji undang-undang terhadap Undang-Undang Dasar Negara Republik Indonesia Tahun 1945".

18 Pasal 24A Ayat (1) UUD 1945: "Mahkamah Agung berwenang mengadili pada tingkat kasasi, menguji peraturan perundang-undangan di bawah undang-undang terhadap undang-undang, dan mempunyai wewenang lainnya yang diberikan oleh undang-undang”. Pasal 20 ayat (2) huruf (b) UU 48 Tahun 2009 disebutkan bahwa "Mahkamah Agung berwenang menguji peraturan perundang-undangan di bawah undang-undang terhadap undang-undang."

19 UU yang meratifikasi perjanjian internasional yang diikuti oleh Indonesia berisi dua pasal, sejak Indonesia merdeka hingga saat ini. Sementara untuk Kepres/Perpres umumnya dua pasal, namun demikian ada yang berisi 3 
Pasal pertama berisi tentang pengesahan, sementara pasal kedua berisi kapan ketentuan mulai berlaku. Bila demikian, instrumen ratifikasi baik berupa UU maupun Perpres memang masuk dalam katagori beschikking.

Dilihat dari tujuan dan formatnya, instrumen ratifikasi merupakan beschikking. Namun bila melihat perjanjian internasional yang disahkan terutama yang bersifat law making treaty, maka ia bersifat pengaturan (regelling). Untuk diketahui materi muatan suatu perjanjian internasional terbagi menjadi dua katagori, yaitu law making treaty dan treaty contract. Law making treaty merupakan perjanjian internasional yang berkonsekuensi suatu negara yang mengikuti akan mengamandemen ketentuan hukum nasionalnya atau memunculkan (introduce) suatu konsep baru. ICCPR merupakan salah satu perjanjian internasional yang masuk dalam katagori law making treaty. Sementara yang masuk dalam katagori treaty contract adalah perjanjian yang tidak membutuhkan transformasi ke dalam hukum nasional, seperti perjanjian batas wilayah negara. Apabila instrumen ratifikasi tidak dapat dibatalkan, menjadi pertanyaan apakah dalam perjanjian internasional yang berkatagori law making treaty, pembatalan baru dilakukan setelah ketentuan dalam perjanjian internasional diterjemahkan ke dalam peraturan perundangundangan.

Kemungkinan kedua dari putusan MK atau MA adalah bila lembaga peradilan ini menyatakan diri berwenang untuk melakukan pembatalan terhadap instrumen ratifikasi berupa UU atau Perpres, terlepas dari materi muatannya bersifat beschikking. Hal ini berarti Indonesia harus keluar dari perjanjian internasional yang telah diikuti.

Sejauh ini setidaknya ada satu putusan Mahkamah Konstitusi terkait permohonan untuk membatalkan perjanjian internasional ke MK. Permohonan diajukan oleh sejumlah lembaga yang tergabung

pasal seperti Keppres Nomor 88 Tahun 2003 tentang Pengesahan ASEAN Framework Agreement on Services. Adapun pasal tambahan berupa ketentuan bila bahasa asli perjanjian (Inggris) bertentangan dengan bahasa terjemahan (Indonesia) maka yang berlaku adalah bahasa asli. 
dalam Aliansi untuk Keadilan Global, untuk membatalkan Undangundang Nomor 38 Tahun 2008 tentang Pengesahan Charter of the Association of Southeast Asian Nations. Para pemohon menilai pemberlakuan Piagam ASEAN yang menyangkut perdagangan bebas merugikan industri dan perdagangan nasional, karena Indonesia harus tunduk dengan segala keputusan yang diambil di tingkat ASEAN. Adapun materi Piagam ASEAN yang diminta untuk diuji adalah Pasal 1 ayat (5) dan Pasal 2 ayat (2) huruf n Piagam ASEAN. Pasal 1 ayat (5) mengatur prinsip pasar tunggal dengan basis produksi tunggal yang berarti pelaksanaan kesepakatan perdagangan ASEAN itu harus sama (homogen). Pasal tersebut yang dianggap yang menjadi landasan bagi ASEAN untuk melakukan perdagangan bebas dengan negara-negara di luar kawasan.

Dalam Putusan Nomor 33 / PUU-IX / 2011, MK menyatakan bahwa mereka berwenang untuk mengadili permohonan, namun dalildalil pemohon tidak beralasan menurut hukum, sehingga menolak seluruh permohonan yang diajukan. Dua Hakim Konstitusi, Hamdan Zoelva dan Maria Farida Indrati, menyatakan pendapat berbeda (dissenting opinion). Menurut keduanya, UU yang diajukan permohonan, yaitu UU ratifikasi, tidak dapat dijadikan objek pengujian UU yang menjadi wewenang MK.

Apabila MK ataupun MA ternyata membatalkan instrumen ratifikasi atau membatalkan pasal yang merupakan hasil transformasi dari suatu perjanjian internasional, menjadi pertanyaan apa yang menjadi konsekuensi hukumnya. Pertama bila MK atau MA membatalkan instrumen ratifikasi maka konsekuensinya adalah Indonesia harus keluar dari perjanjian internasional yang telah diikuti. Padahal untuk keluar dari suatu perjanjian internasional bukanlah hal yang mudah. Ia tidak mudah karena ada perjanjian internasional yang tidak mengatur tentang pengunduran diri (withdrawal) sebagai negara anggota. Sebagai contoh adalah Framework Agreement on Comprehensive Economic Co-operatioan between the People's Republic of China and the Association of South East Asian Nations ${ }^{20}$ yang

20 Dokumen dapat diakses di http://www.asean-cn.org/Item/1065.aspx, diakses $2 / 5 / 2011$. 
merupakan basis bagi ASEAN-China Free Trade Agreement (ACFTA) yang tidak mengatur ketentuan tentang pengunduran diri.

Kalaupun ada pasal yang mengatur tentang pengunduran diri, pengunduran diri dari keanggotaan suatu perjanjian internasional juga tidak sesederhana yang diatur dalam withdrawal clause. Secara sosiologis akan ada tekanan terhadap negara yang akan mengundurkan diri. Tekanan dari negara-negara anggota lain agar suatu negara tidak mengundurkan diri kerap dilakukan. Sebagai contoh ketika Korea Utara hendak keluar dari Non Proliferation Treaty ${ }^{21}$ maka negara-negara seperti Amerika Serikat, Jepang dan lain-lain berupaya agar Korea Utara tidak melakukannya.

Hal ini juga bisa terjadi dengan Indonesia bila ternyata UU pengesahan Perjanjian Pembentukan WTO dibatalkan oleh MK. ${ }^{22}$ Kebanyakan negara maju memiliki kepentingan agar Indonesia tetap menjadi anggota WTO, karena pasar Indonesia sangat menjanjikan bagi produsen negara-negara maju. Oleh karenanya negara maju akan berupaya keras dengan berbagai cara agar Indonesia tetap menjadi anggota WTO. Apabila ini yang terjadi maka Indonesia dalam posisi yang dilematis. Secara domestik pemerintah diminta keluar dari suatu perjanjian internasional, namun secara internasional Indonesia diminta untuk tetap menjadi anggota.

Kedua, apabila MK atau MA ternyata membatalkan pasal dalam suatu peraturan perundang-undangan yang merupakan hasil transformasi suatu perjanjian internasional maka konsekuensinya adalah Indonesia dianggap tidak melaksanakan kewajibannya. Bila ini terjadi maka Indonesia berpotensi untuk dipermasalahkan oleh negara anggota lainnya.

Dari dua skenario dampak hukum yang telah diuraikan, ternyata pembatalan UU atau Perpres instrumen ratifikasi ataupun hasil transformasi ke dalam peraturan perundang-undangan oleh MK atau MA dapat berdampak sangat luas. Ini berbeda dengan pembatalan

21 Treaty on the Non-Proliferation of Nuclear Weapons, 1968

22 Agreement Establishing the World Trade Organization.Dokumen dapat diakses di http://www.wto.org/english/docs_e/legal_e/legal_e.htm, diakses $17 / 5 / 2011$. 
ketentuan dalam UU atau peraturan perundang-undangan di bawah UU yang dilakukan oleh MK atau MA. Dalam konteks demikian pembatalan tidak akan membawa komplikasi dan kerumitan secara internasional. Ketentuan yang dibatalkan dapat direvisi sesuai dengan prosedur yang ada. Mengingat pembatalan instrumen ratifikasi memiliki konsekuensi internasional maka para hakim di MK atau MA yang memutus permohonan pembatalan harus memikirkan dampak dari pembatalan tersebut, terutama dari dimensi internasionalnya. Namun demikian kehati-hatian para hakim MK dan MA tidak boleh disalahgunakan atau dijadikan tameng oleh pemerintah dan DPR untuk mengabaikan kewajiban memastikan keselarasan perjanjian internasional yang akan diikuti dengan UUD.

Pada masa-masa mendatang, cara berpikir para penyelenggara negara harus diubah ketika Indonesia akan mengikutisuatu perjanjian internasional. Pemerintah dan DPR harus memastikan keselarasan antara perjanjian internasional yang akan diikuti dengan UUD. Ada paling tidak tiga hal yang harus dilakukan ke depan. Pertama, bila pemerintahmemilikikesempatanuntukberperandalammerumuskan ketentuan dalam rancangan atau teks perjanjian internasional, maka perlu untuk memastikan rumusan tersebut selaras dengan UUD. Kedua, pemerintah ketika menyiapkan naskah akademik UU yang menjadi instrumen ratifikasi perlu melakukan pembahasan secara khusus terkait dengan keselarasan antara perjanjian internasional yang akan diikuti dengan UUD. ${ }^{23}$ Demikian pula DPR sebagai pihak yang diminta persetujuan oleh pemerintah perlu untuk melakukan pengecekan apakah perjanjian internasional yang diajukan oleh pemerintah untuk disahkan telah selaras dengan UUD. Bila tidak, DPR tentu dapat menolak untuk melakukan pengesahan.

Cara demikian juga berlaku ketika pemerintah melakukan pengesahan dengan menggunakan Perpres. Meski naskah akademik

23 Meski tidak ada kewajiban suatu Rancangan UU (RUU) untuk disandingkan dengan Naskah Akademik dalam UU 10 Tahun 2004, namun saat ini telah ada kelaziman antara Pemerintah dengan DPR agar sebuah RUU disandingkan dengan Naskah Akademik. RUU yang disandingkan dengan Naskah Akademik akan mendapat prioritas pembahasan. 
tidak disyaratkan namun pembahasan terkait keselerasan dengan UUD wajib dilakukan dalam suatu dokumen yang resmi. Memang instrumen ratifikasi berupa UU atau Perpres lebih merupakan masalah prosedural untuk mendapatkan persetujuan dari pihak yang berwenang dalam suatu negara. Pertanyaannya adalah, apa dasar atau patokan untuk memberikan persetujuan atau tidak; apakah pertimbangan kepentingan nasional, sosiologis atau filosifis saja, ataukah juga pertimbangan yuridis.

Bila pertimbangan yuridis dilakukan, pertanyaannya apa yang menjadi patokan. Dalam konteks pertanyaan terakhir inilah diperlukan kajian atas substansi yang diatur dalam perjanjian internasional, apakah ada atau tidak ketentuannya yang bertentangan dengan norma dalam UUD. Bila ada dan ketentuan tersebut tidak bisa dilakukan pengenyampingan (reservation) keberlakuannya, maka perjanjian internasional yang dimaksud harus ditolak. Ini semua untuk memastikan di kemudian hari bila instrumen ratifikasi diuji-materikan maka ada argumentasi yang kuat bahwa perjanjian internasional yang diikuti sudah dipastikan tidak ada yang bertentangan dengan UUD.

Hal lain yang juga perlu dipikirkan adalah bagaimana dengan perjanjian internasional yang akan diikuti oleh Indonesia namun tidak melalui proses ratifikasi baik oleh perjanjian internasional dimaksud maupun oleh pemerintah sebagai pemegang otoritas yang menentukan perlu tidaknya proses ratifikasi. Dalam situasi demikian, ada dua isu yang muncul. Pertama, apakah dalam persiapan mengikuti perjanjian internasional ada forum untuk memastikan keselarasan dengan UUD. Isu kedua adalah apakah rakyat dapat melakukan uji materi terhadap perjanjian internasional yang tidak melalui proses ratifikasi. Bila tidak, apakah hak rakyat untuk mengawasi pemerintah ketika mengikatkan diri dalam suatu perjanjian internasional dihilangkan eksistensinya.

Terakhir, ke depan pemerintah perlu ekstra hati-hati ketika hendak mengikuti perjanjian internasional. Pemerintah tidak seharusnya mengikuti perjanjian internasional dengan alasan pencitraan 
atau anggaran telah dialokasikan. ${ }^{24}$ Bahkan, bila ada suatu perjanjian internasional yang substansinya baik untuk diberlakukan di Indonesia, namun terdapat banyak pengaturan yang bertentangan dengan Konstitusi, maka pemerintah cukup mengadopsi substansi yang baik ke dalam peraturan perundang-undangan. ${ }^{25}$ Dengan mengadopsi berarti pemerintah memiliki kebebasan untuk memilih mana ketentuan dalam perjanjian internasional yang hendak diberlakukan dan mana yang tidak akan diberlakukan.

\section{Kewajiban Mentransformasikan ke dalam Hukum Nasional}

Dalam sejumlah buku teks yang membahas tentang perjanjian internasional, ${ }^{26}$ perjanjian internasionalbila dilihat darisubstansiyangdiatur dibedakan menjadi dua katagori. Kategori pertama adalah perjanjian internasional yang memiliki substansi "treaty-contract". Perjanjian internasional demikian akan memiliki ketentuan-ketentuan yang bersifat aplikatif, semisal perjanjian internasional antar dua negara terkait dengan tapal batas atau perjanjian internasional untuk pinjam meminjam. Starke menggambarkannya sebagai "a treaty between two or only a few states, dealing with a special matter concerning these states exclusively." ${ }^{27}$

Katagori kedua adalah perjanjian internasional yang memiliki

24 Sebagai contoh Presiden BJ Habibie pernah membanggakan Indonesia telah meratifikasi 7 ILO Conventions yang berkatagori inti (core), sementara Amerika Serikat hanya 2 ILO Conventions. Namun demikian dalam kenyataannya kondisi para buruh di Indonesia tidak lebih baik dari Amerika Serikat.

25 Bila menilikUU Nomor 39 Tahun 1999 tentang Hak Asasi Manusia, misalnya, telah banyak ketentuan dalam ICCPR yang diadopsi dalam UU tersebut. Berdasarkan ini Indonesia tidak terikat dengan sejumlah kewajiban yang diharuskan oleh ICCPR seperti menyampaikan setiap kemajuan dibidang HAM mengingat kemajuan kerap sangat lamban. Namun demikian pada tahun 2005, Indonesia meratifikasi ICCPR meski UU 39/1999 belum dijalankan secara baik oleh pemerintah.

26 Penyebutan perjanjian internasional dapat bermacam-macam, seperti Agreement, Convention, Covenant, Treaty, Protocol dan lain-lain.

27 I.A. Shearer, Starke's International Law (United Kingdom: Butterworth \& Co. Ltd., edisi kesebelas, 1994), hlm. 37. 
substansi "law-making" atau disebut "law-making treaties". Perjanjian internasional katagori ini akan memunculkan pembentukan kaedah (law making). Hal ini karena tujuan dari perjanjian internasional dalam katagori law-making adalah negara diharapkan berperilaku tertentu. Starke menggambarkannya sebagai perjanjian internasional yang "lay down rules of universal or general application." 28

Meski sejumlah sarjana tidak menganggap kategorisasi perjanjian internasional berdasarkan substansi terlalu penting, ia sesungguhnya penting dalam pembahasan tentang kewajiban negara untuk mentransformasi ketentuan dalam perjanjian internasional ke dalam peraturan perundang-undangan pasca keikutsertaan. Pada perjanjian internasional yang berkatagori law-making, maka negara mempunyai kewajiban untuk mentransformasikan ketentuan di dalamnya ke dalam hukum nasional. Alasan mendasar dibutuhkannya transformasi karena perjanjian internasional yang berkatagori lawmaking bertujuan untuk merubah ketentuan yang berlaku dalam suatu negara.

Kewajiban untuk melakukan transformasi dalam perjanjian internasional yang berkatagori law making kerap diamanatkan secara tertulis. Sebagai contoh dalam Pasal XVI ayat (4) WTO Agreement disebutkan, "Each Member shall ensure the conformity of its laws, regulations and administrative procedures with its obligations as provided in the annexed Agreements". ${ }^{29}$ Demikian pula dalam Pasal 4 ayat (1) Convention against Torture and Other Cruel, Inhuman or Degrading Treatment or Punishment, disebutkan bahwa, "Each State Party shall ensure that all acts of torture are offences under its criminal law". ${ }^{30}$

Mencermati ketentuan tersebut, tidak bisa lain selain ditafsirkan adanya keharusan suatu negara untuk menerjemahkan suatu perjanjian internasional yang telah diikuti ke dalam peraturan perundangundangan nasional. Tulisan ini hendak mengkaji perdebatan yang

28 Shearer, Starke's International Law, hlm. 37.

29 Agreement Establishing the World Trade Organization, dapat diakses di http: / / www.wto.org/english/docs_e/legal_e/04-wto.pdf

30 Convention against Torture and Other Cruel, Inhuman or Degrading Treatment or Punishment, dapat diakses di http:/ / www.hrweb.org/legal/ cat.html 
sering mengemuka di Indonesia, yaitu apakah pasca keikutsertaan Indonesia dalam perjanjian internasional yang berkatagori law-making harus diikuti dengan transformasi ke dalam peraturan perundangundangan.

Transformasi perjanjian internasional ke dalam hukum nasional menimbulkan pro dan kontra. Bagi mereka yang menganggap bahwa transformasi ketentuan perjanjian internasional ke dalam peraturan perundang-undangan tidak diperlukan mendasakan pada pendapat Mochtar Kusuma-atmadja. Dalam Pengantar Hukum Internasional, Mochtar berpendapat bahwa Indonesia akan langsung terikat pada perjanjian internasional yang telah diikutinya tanpa perlu melakukan proses transformasi ke dalam peraturan perundang-undangan. Beliau menguraikan pendapatnya sebagai berikut , “... penulis berpendapat bahwa kita tidak menganut teori transformasi apalagi sistem Amerika Serikat. Kita lebih condong pada sistem negara-negara Eropa Kontinental yang disebut di halaman terdahulu, yakni langsung menganggap diri kita terikat dalam kewajiban melaksanakan dan menaati semua ketentuan perjanjian dan konvensi yang telah disahkan tanpa perlu mengadakan lagi perundang-undangan pelaksanaan (implementing legislation)". ${ }^{31}$

Uraian Mochtar tersebut dimaksudkan untuk mengedepankan teori yang dianut oleh Indonesia yaitu teori monoisme dengan primat hukum internasional. Alasan mengapa Indonesia menganut teori monosime dengan primat hukum internasional versi Eropa Kontinental karena Indonesia sebagai negara "kerap belum atau lalai memproses kewajiban kita berdasarkan perjanjian internasional yang telah diadakan ke dalam bentuk perundang-undangan nasional." ${ }_{32}$

Meskipun demikian, Mochtar berpendapat, "namun, dalam beberapa hal menurut pendapat penulis pengundangan dalam undang-undang nasional adalah mutlak diperlukan yakni antara lain apabila diperlukan perubahan dalam undang-undang nasional yang langsung menyangkut hak warga negara sebagai perorangan.” Dari

31 Mochtar Kusuma-atmadja dan Etty R. Agoes, Pengantar Hukum Internasional (Bandung: PT Alumni, 2003), hlm.92.

32 Kusumaatmajda dan Agoes, Pengantar Hukum Internasional, hlm. 93. 
apa yang disampaikan oleh Mochtar, sebenarnya merupakan suatu kewajiban untuk melakukan transformasi. Namun karena Indonesia mengalami masalah untuk melakukan proses transformasi maka Mochtar berpendapat bahwa perjanjian internasional tidak perlu ditransformasikan ke dalam hukum nasional.

Pendapat demikian tentunya tidak lagi bisa digunakan sebagai tameng oleh Indonesia ketika pemerintah tidak mampu untuk melakukan transformasi ketentuan perjanjian internasional ke dalam peraturan perundang-undangan. Ada paling tidak tiga alasan mengapa pemerintah tidak lagi dapat menggunakannya sebagai tameng. Pertama, perjanjian internasional sebagaimana diketahui mendasarkan pada subyek hukum internasional, seperti negara dan organisasi internasional. Akan menjadi pertanyaan, apakah ketentuan dalam perjanjian internasional dapat juga mengikat subyek hukum nasional, baik perdata, pidana, tata negara dan administrasi negara. Kedua, adalah tidak lazim bila dalam proses hukum di tingkat nasional pihak-pihak tertentu menggunakan perjanjian internasional untuk pemenuhan atas haknya. Di Indonesia, misalnya, hampir tidak ada gugatan perdata ataupun tuntutan pidana yang didasarkan pada perjanjian internasional. Ketiga, kenyataan sejumlah perjanjian internasional mengharuskan penyesuain terhadap peraturan perundang-undangan, bahkan memantaunya apakah telah dilakukan transformasi, mengindikasikan perlunya pemerintah melakukan kewajiban untuk menerjemahkan ketentuan dalam perjanjian internasional ke dalam peraturan perundang-undangan.

Bagi aparat penegak hukum, seperti hakim, tentu mereka akan menggunakan hukum nasional dalam membuat putusan dan memberi keadilan. Hakim akan merujuk pada peraturan perundangundangan yang mengatur tentang sumber hukum nasional sebagai acuan penggunaan hukum. Dalam hal ini menjadi pertanyaan, apakah pasca proses keikutsertaan, baik melalui ratifikasi atau tidak, aparat penegak hukum akan langsung terikat dalam ketentuan perjanjian internasional tersebut, atau pemerintah Indonesia mempunyai kewajiban untuk melakukan penyisiran terlebih dahulu. Setelah diketahui mana ketentuan yang harus diamandemen atau 
dimunculkan secara baru, maka pemerintah melakukan revisi. Setelah terakomodasi dalam berbagai produk hukum nasional barulah ketentuan dalam perjanjian internasional dapat dijalankan atau dijadikan dasar oleh aparat penegak hukum.

Bila menilik konteks Indonesia, ada sejumlah sumber hukum nasional, salah satunya adalah peraturan perundang-undangan. Berdasarkan ketentuan UU 12 Tahun 2011, tidak diatur tentang perjanjian internasional yang telah diikuti oleh Indonesia. Oleh karenanya perjanjian internasional yang telah diikuti tidak dapat dijadikan dasar hukum bagi aparat penegak hukum, termasuk polisi, jaksa, advokat dan hakim. Dengan demikian, terhadap perjanjian internasional yang bersifat law-making, maka negara memiliki kewajiban untuk menerjemahkannya ke dalam peraturan perundang-undangan agar bisa dijalankan.

Keharusan untuk mentransformasi isi perjanjian internasional ke dalam hukum nasional juga dilandasi alasan ketentuan ratifikasi tidak dapat dijadikan sebagai dasar untuk memberlakukan perjanjian internasional dalam proses hukum di tingkat nasional. ${ }^{33}$ Memang ada pihak yang mengargumentasikan bahwa keikutsertaan Indonesia dalam suatu perjanjian internasional biasanya dilakukan dengan ratifikasi, baik dalam bentuk UU maupun Keputusan Presiden (kini Perpres). Namun atas pendapat ini dapat diajukan keberatan. Pertama, produk hukum untuk meratifikasi hanyalah tanda persetujuan untuk mengikatkan diri pada suatu perjanjian internasional. Ratifikasi ini biasanya diamanatkan dalam perjanjian

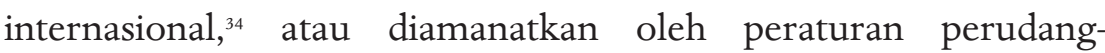

33 MK dalam pertimbangan putusannya nomor 13/PUU-XVI/2018 menyatakan, "tahapan pengesahan (menurut hukum nasional) juga merupakan konsekuensi dari suatu perjanjian internasional yang mempersyaratkan adanya pengesahan (ratifikasi) sebagai pernyataan untuk terikat (consent to bound) pihak-pihak yang menjadi peserta dalam perjanjian internasional yang bersangkutan. Dengan demikian, tahap pengesahan (menurut hukum nasional) terhadap suatu perjanjian internasional adalah sekaligus sebagai instrumen yang menjadikan suatu perjanjian internasional sebagai bagian dari hukum nasional".

34 Sebagai contoh pasal 48 ayat (2) dari International Covenant on Civil and Political Rights menyebutkan, "The present Covenant is subject to 
undangan. ${ }^{35}$ Produk hukum ini tidak bisa serta merta dijadikan dasar untuk memberlakukan ketentuan-ketentuan yang cukup rinci dalam perjanjian internasional.

Perlu diketahui, UU ataupun Perpres untuk meratifikasi hanya berisi dua pasal. Pasal pertama berisi ketentuan tentang pengesahan suatu perjanjian internasional, ${ }^{36}$ dan pasal kedua berisi mulai berlakunya peraturan tersebut. ${ }^{37}$ Dalam banyak hal, banyak ketentuan yang ada dalam perjanjian internasional yang diikuti oleh Indonesia yang bertentangan dengan hukum nasional. Dalam konteks demikian maka hukum nasional yang bertentangan harus diamandemen, bahkan dimunculkan secara baru bila tidak terdapat pengaturan. Hukum nasional yang bertentangan terkadang ada pada level UU, peraturan pemerintah, Perpres, bahkan hingga peraturan menteri ataupun peraturan daerah. Oleh karenanya perlu dilakukan penyisiran ketentuan-ketentuan mana yang ada dalam peraturan perundang-undangan yang bertentangan. Amandemen harus dilakukan terhadap semua ketentun tersebut sehingga aparat penegak hukum tidak terombang-ambing antara ketentuan dalam perjanjian internasional dengan ketentuan dalam peraturan perundang-undangan.

Secara konkret Indonesia pernah mengalami ketiadaan transformasi peraturan perundang-undangan yang berakibat tidak dapat dijalankannya perjanjian internasional. Salah satunya adalah ketika Convention on the Recognition and Enforcement of Foreign Arbitral Awards

ratification".

35 Lihat kembali catatan kaki nomor 14.

36 Sebagai contoh dalam UU Nomor 5 Tahun 2009 tentang Pengesahan United Nations Convention Against Transnational Organized Crime pada Pasal 1 ayat (1) disebutkan, "Mengesahkan United Nations Convention Against Transnational Organized Crime (Konvensi PerserikatanBangsa-Bangsa Menentang Tindak Pidana Transnasional yang Terorganisasi) dengan Pensyaratan (Reservation)terhadap Pasal 35 ayat (2)".

37 Dalam UU Nomor 5 Tahun 2009, pada Pasal 2 disebutkan, "UndangUndang ini mulai berlaku pada tanggal diundangkan. Agar setiap orang mengetahuinya, memerintahkan pengundangan Undang-Undang ini dengan penempatannya dalam Lembaran Negara Republik Indonesia." 
(selanjutnya disebut "New York Convention") ${ }^{38}$ telah diikuti oleh Indonesia melalui ratifikasi dengan Keputusan Presiden Nomor 34 Tahun $1981 .{ }^{39}$ Lembaga peradilan masihbelummenjalankanketentuan New York Convention untuk mengakui dan melaksanakan putusan arbitrase asing karena lembaga peradilan membutuhkan peraturan pelaksanaan. Pada masa ini perdebatan muncul antara Sudargo Gautama dan Hakim Agung Asikin Kusuma-atmadja. ${ }^{40}$ Sudargo pada

38 Dokumen dapat diakses di http://www.uncitral.org/pdf/english/texts/ arbitration/NY-conv/XXII_1_e.pdf

39 Keputusan Presiden Nomor 34 Tahun 1981 tentang Mengesahkan "Convention on the Recoginition and Enforcement of Foreign Arbitral Awards,” yang telah ditandatangani di New York pada tanggal 10 Juni 1958 dan telah mulai berlaku pada tanggal 7 Juni 1959.

40 Dalam bukunya Hukum Dagang \& Arbitrase Internasional, Sudargo Gautama mengungkapkan halberikut, "Peraturan Mahkamah AgungNo. 1 tahun 1990 tentang Tata Cara Putusan Arbitrase Asing memang sudah lama dinantikan dan telah dijanjikan sejak beberapa waktu berselang. Tepatnya pada waktu diadakan Seminar dalam rangka peringatan Dies Natalis Fakultas Hukum Universitas Indonesia di Jakarta tahun 1985. Pada waktu itu telah terdapat perbedaan pendapat antara penulis dan Ketua Muda Bidang Hukum Perdata Tertulis dari Mahkamah Agung Prof. R. Asikin Kusumaatmadja SH. Dalam makalah penulisa dikemukakan bahwa Konvensi New York dari PBB tahun 1958 yang oleh Keppres R.I. No. 34 tahun 1981 Lembara Negara 1981 No. 40 tgl. 5 Agustus 1981 telah disahkan pula untuk berlaku bagi Republik Indonesia, sesungguhnya tidak memerlukan lagi suatu peraturan tersendiri karena merupakan Treaty yang sifatnya "Self Executing". Jadi, sesungguhnya tidak diperlukan lebih lanjut suatu peraturan pelaksanaan yang dikeluarkan oleh pemerintah R.I. Karena dalam Konvensi itu sendiri tercantum bahwa cara pelaksanaan putusan arbitrase yang diucapkan di luar negeri adalah sama dengan cara pelaksanaan arbitrase yang berlaku untuk putusan Arbitrase dalam negeri anggota masing-masing Konvensi ini. Jadi cara untuk melaksanakan misalnya putusan arbitrase luar negeri adalah sama dengan cara melaksanakan putusan BANI (Badan Arbitrase Nasional Indonesia) yang diucapkan di dalam wilayah Republik Indonesia. ... Pada saat pertukaran pikiran berlangsung pada diskusi Fakultas Hukum Universitas Indonesia bersangkutan ini, Prof. Asikin Kusumaatmadja mengemukakan bahwa masih perlu cara mengatur bagaiman tata caranya untuk pelaksanaan putusan arbitrase luar negeri ini di Indonesia. Beliau menganggap perlu agar bersikap hati-hati karena berhubungan dengan hukum luar negeri.Tidak semua Pengadilan Negeri di Indonesia dianggap cukup dapat mengikuti irama Hukum Dagang Internasional. Ada kekhawatiran bahwa Pengadilanpengadilan Negeri setempat, apalagi dari tempat-tempat terpencil, akan menghadapi kesukaran secara teknis dan juga praktis dalam pelaksanaan putusan-putusan luar negeri mengenai arbitrase yang hendak dilaksanakan 
intinya berpendapat segera setelah New York Convention diratifikasi maka lembaga peradilan harus segera mengakui dan melaksanakan putusan arbitrase asing. Alasannya karena New York Convention merupakan perjanjian internasional yang bersifat "self executing". Tidak demikian dengan pendapat Hakim Agung Asikin Kusumaatmadja yang mensyaratkan peraturan pelaksanaan sebelum dapat diterapkan oleh hakim di pengadilan. Dalam kenyataannya New York Convention tidak diberlakukan hingga dikeluarkan Peraturan Mahkamah Agung Nomor 1 Tahun 1990. Peraturan ini berisi tentang tata cara pelaksanaan Putusan Arbitrase Asing. ${ }^{41}$

\section{E. Studi Kasus Capetown Convention}

Indonesia telah lama ikut dalam sejumlah perjanjian internasional. Intensitas untuk mengikuti perjanjian internasional semakin tinggi pasca pemerintahan Soeharto. Sejumlah perjanjian internasional berkategori law-making diikuti, sepertiConvention Against Transnational Organized Crime, Convention Against Corruption, Convention on the Elimination of All Forms of Discrimination against Women, Convention against Torture and Other Cruel, Inhuman or Degrading Treatment or Punishment. Hanya saja pasca keikutsertaan, Indonesia masih belum melakukan proses tranformasi terhadap berbagai perjanjian internasional tersebut. Kalaupun telah dilakukan transformasi ke dalam peraturan perundang-undangan, ternyata dilakukan secara tidak memadai.

Di sini akan dibahas tentang bagaimana pemerintah Indonesia melakukan transformasi terhadap ketentuan dalam Convention on International Interests in Mobile Equipment (Konvensi tentang Kepentingan Internasional dalam Peralatan Bergerak ${ }^{42}$ berserta Protocol

di dalam wilayah Republik Indonesia ini.” Baca: Sudargo Gautama, Hukum Dagang \& Arbitrase Internasional (Bandung: Citra Aditya Bakti, 1991), hlm. 1-2.

41 Dokumen dapat diakses di http://legislasi.mahkamahagung.go.id/docs/ Peraturan\%20MA/Perma_1990_1_TATA\%20CARA\%20PELAKSANAAN\%20PUTUSAN\%20ARBITRASE\%20ASING.pdf

42 Dokumen dapat diakses di http: / www.unidroit.org/english/conventions / mobile-equipment/mobile-equipment.pdf 
to the Convention on International Interests in Mobile Equipment on Matters Specific to Aircraft Equipment (Protokol pada Konvensi tentang Kepentingan Internasional dalam Peralatan Bergerak mengenai Masalah-masalah Khusus pada Peralatan Pesawat Udara) ${ }^{43}$ (selanjutnya disebut "Capetown Convention") pasca keikutsertaan Indonesia. Pemerintah Indonesia meratifikasi Capetown Convention dengan Peraturan Presiden Nomor 8 Tahun 2007.44

Capetown Convention adalah suatu Konvensi yang dibentuk dalam rangka menyeragamkan (standardize) secara universal transaksi pembiayaan yang terkait dengan benda bergerak, khususnya pesawat udara dan mesin pesawat. Ini mengingat dalam transaksi pembiayaan dan penyewaan antar negara kerap ditemui masalah eksekusi (enforcement) dari barang jaminan. Dalam konteks demikian dan untuk memfasilitasi cara pembiayaan yang didasarkan pada aset dan sewa (asset-based financing and leasing) maka diatur ketentuan yang ada dalam Konvensi. ${ }^{45}$

Sebagaimana dinyatakan dalam Pasal 2 ayat (1) Capetown Convention, "provides for the constitution and effects of an international interest in certain categories of mobile equipment and associated rights." 46 Adapun yang dimaksud dengan "international interests" adalah hak jaminan yang dipegang oleh kreditur berdasarkan Konvensi. ${ }^{47}$ International interests harus dibedakan dengan national interests yang didefinisikan sebagai hak jaminan oleh kreditur berdasarkan hukum nasional suatu negara. ${ }^{48}$ Secara nyata katagori benda yang dimaksud

43 Dokumen dapat diakses di http: / / www.unidroit.org/english/ conventions / mobile-equipment/aircraftprotocol.pdf

44 Peraturan Presiden Nomor 8 Tahun 2007 tentang Pengesahan Convention on International Interests in Mobile Equipment (Konvensi tentang Kepentingan Internasional dalam Peralatan Bergerak) Beserta Protocol to the Convention on International Interests in Mobile Equipment on Matters Specific to Aircraft Equipment (Protokol pada Konvensi tentang Kepentingan Internasional dalam Peralatan Bergerak Mengenai MasalahMasalah Khusus pada Peralatan Pesawat Udara).

45 Dapat dibaca dalam konsiderans dari Capetown Convention.

46 Pasal 2 ayat (1) Capetown Convention.

47 Pasal 1 huruf (o) Capetown Convention.

48 Pasal 1 huruf (r) Capetown Convention. 
dalam Konvensi diatur dalam Pasal 2 ayat (3) yaitu (a) airframes, aircraft engines and helicopters; (b) railway rolling stock; and (c) space assets. ${ }^{49}$ Benda yang dijadikan jaminan akan mendapat prioritas bagi krediturnya apabila didaftarkan pada International Registry. Konvensi memandatkan untuk dibentuk International Registry. ${ }^{50}$

Konvensi yang terdiri dari 62 pasal ini dilengkapi dengan sebuah Protokol yang secara khusus mengatur perlengkapan yang khas bagi perlengkapan pesawat udara. ${ }^{51}$ Dalam Protokol ditentukan bahwa yang dimaksud dengan aircraft objects adalah airframes, aircraft engines dan helicopters..$^{52}$ Dengan adanya ketentuan Konvensi Capetown yang telah ditransformasikan ke dalam hukum nasional pada prinsipnya mereka yang memberi pembiayaan atau menyewakan benda-benda pesawat udara memiliki kemampuan untuk mendapatkan penyelesaian dalam suatu proses kepailitan. Ini tentunya menguatkan perlakuan terhadap mereka yang melakukan pembiayaan atau menyewa aircraft objects.

Capetown Convention diikuti oleh dua katagori negara. Pertama adalah negara yang menjadi domisili dari perusahaan yang memproduksi pesawat udara dan untuk memperlancar penjualan dan penyewaan pesawat memiliki bank yang secara khusus memberi kredit yang disebut sebagai Bank atau Lembaga Ekspor Impor (selanjutnya disebut "Negara Produsen"). Kedua adalah negara yang menjadi domisili dari perusahaan penerbangan yang membeli pesawat udara (selanjutnya disebut "Negara Konsumen").

Bagi Negara Produsen, Capetown Convention memberi keuntungan berupa pengaturan yang jelas dan berstandar sama terkait dengan pembiayaan dan penyewaan pesawat udara di berbagai negara yang berkatagori Negara Produsen. Oleh karenanya perusahaan penerbangan dari Negara Produsen akan mendapatkan pengurangan harga bila Negara Produsen ikut dalam Capetown Convention. Ini

49 Pasal 2 ayat (3) Capetown Convention.

50 Pasal 16 ayat (1) Capetown Convention.

51 Protocol to the Convention on International Interests in Mobile Equipment on Matters Specific to Aircraft Equipment.

52 Pasal 1 ayat (2) huruf (c) Protocol to the Convention on International Interests in Mobile Equipment on Matters Specific to Aircraft Equipment. 
tentunya merupakan keuntungan bagi Negara Produsen mengingat perusahaan penerbangnya dapat membeli atau menyewa pesawat lebih murah. Harga ini akan berdampak pada harga yang harus dibayarkan oleh pengguna pesawat komersial berjadwal.

Tidak heran jika Indonesia sebagai Negara Konsumen melihat urgensi untuk ikut serta dalam Konvensi. Sebagai negara kepulauan harus diakui lalu lintas penumpang yang menggunakan angkutan udara terus bertambah dan karenanya kebutuhan akan pembelian dan penyewaan pesawat udara sangat tinggi.

Proses keikutsertaan Indonesia dalam Capetown Convention terhitung cepat. Capetown Convention yang baru berlaku (enter into force) pada tanggal 1 Maret 2006, lima tahun setelah teks Konvensi diadopsi, diratifikasi oleh Indonesia pada tahun 2007. Segera setelah diratifikasi muncul perdebatan apakah Capetown Convention dapat diberlakukan tanpa adanya proses transformasi ke dalam peraturan perundang-undangan. Untuk menghilangkan keraguan ini, ketika UU Penerbangan 1992 hendak direvisi maka berbagai hal yang terkait dengan Capetown Convention dimasukkan ke dalam revisi. Akhirnya sejumlah ketentuan dalam Capetown Convention diakomodasi dalam UU Penerbangan 2009. Apa yang dilakukan oleh pembentuk UU merupakan suatu jalan pintas. Pembentuk UU mentransformasi begitu saja ketentuan dalam Capetown Convention ke dalam UU Penerbangan 1992. Pembentuk UU tidak melakukan penyisiran terhadap peraturan perundang-undangan yang telah ada yang berpotensi bertentangan ataupun tidak diatur.

Bila ditilik ketentuan dalam Bab IX yang berjudul Kepentingan Internasional atas Objek Pesawat Udara dari UU Penerbangan 2009 maka belum dirasa memadai. Ketentuan yang dimulai dari Pasal 71 hingga 82 berisi transformasi secara umum atas Capetown Convention. Ada beberapa alasan mengapa pengaturan dalam Pasal 71 hingga 82 tidak memadai sebagai proses transformasi atas Capetown Convention. Pertama, penerjemahan tidak dilakukan secara rinci sebagaimana pengaturan dalam Capetown Convention. Kedua, pengaturan yang seharusnya dimuat dalam berbagai peraturan perundang-undangan, seperti UU Kepailitan, dimuat dalam UU 
Penerbangan 2009. Pemuatan dalam UU Penerbangan 2009 akan tidak diketahui oleh para aparat penegak hukum yang berkecimpung dalam dunia penerbangan.

Padahalketentuan dalamUUPenerbangan 2009berpotensiuntuk bertentangan dengan UU Kepailitan. Dalam konteks ini, pembentuk UU sepertinya ingin mengantisipasi dengan cara merumuskan Pasal 82. Pasal 82 UU Penerbangan 2009 menyebutkan, "ketentuan dalam konvensi internasional mengenai kepentingan internasional dalam peralatan bergerak dan protokol mengenai masalah-masalah khusus pada peralatan pesawat udara, di mana Indonesia merupakan pihak mempunyai kekuatan hukum di Indonesia dan merupakan ketentuan hukum khusus (lex specialis)." Menjadi pertanyaan, apakah ketentuan yang terdapat dalam Pasal 82 diakui dan dilaksanakan oleh aparat penegak hukum, terutama hakim, apakah hakim tidak akan mengatakan UU Kepailitan justru merupakan ketentuan hukum khusus mengingat Capetown Convention berhubungan erat dengan masalah kepailitan. Jawaban atas pertanyaan ini masih menjadi suatu misteri sebelum adanya putusan pengadilan yang terkait dengan masalah ini.

\section{F. Kesimpulan}

Dari uraian di atas dapat disimpulkan, ada dua kewajiban yang harus dilakukan negara dalam proses ratifikasi perjanjian internasional. Kewajiban pertama adalah memastikan keselarasan perjanjian internasional dengan Konstitusi (UUD 1945). Keselarasan ini diperlukan karena, pertama, Konstitusi merupakan norma tertinggi dalam hirarki peraturan perundang-undangan Indonesia; kedua, untuk memastikan kesamaan persepsi pemerintah ketika hendak mengikuti suatu perjanjian internasional dengan persepsi rakyat; dan ketiga, untuk memastikan terhindarnya intervensi terselubung yang dilakukan oleh negara lain terhadap kedaulatan negara mengingat perjanjian internasional kerap dijadikan instrumen politik oleh satu negara terhadap negara lain. Kewajiban kedua adalah mentransformasikan perjanjian internasional ke dalam hukum nasional. 
Kewajiban transformasi ini, terutama pada perjanjian internasional yang memiliki substansi "law making treaties", dilakukan untuk mengubah ketentuan yang berlaku dalam suatu negara, dalam hal ini berarti perlu penerjemahan ketentuan dalam perjanjian internasional ke dalam peraturan perundang-undangan suatu negara. Hal demikian dikarenakan dokumen ratifikasi tidak dapat dijadikan dasar untuk memberlakukan perjanjian internasional dalam proses hukum di tingkat nasional.

\section{Daftar Pustaka}

\section{Artikel/Buku/Laporan}

Apeldoorn, L.J. van. Pengantar Ilmu Hukum. Jakarta: Noor Komala, 1962.

Gautama, Sudargo. Hukum Dagang \& Arbitrase Internasional. Bandung: Citra Aditya Bakti, 1991.

Http: / / www.asean-cn.org/Item/1065.aspx. Diakses 2/5/2011.

Http: / / www.austlii.edu.au/ au/ other/dfat/treaties / 1980/23.html.

Diakses 11/5/2011.

Http: / / www.dfat.gov.au/geo/indonesia/ind-aus-sec06.html. Diakses $11 / 5 / 2011$.

Http: / / legislasi.mahkamahagung.go.id/ docs / Peraturan\%20MA/

Perma_1990_1_TATA\%20CARA\%20PELAKSANAAN\%20 PUTUSAN\%20ARBITRASE\%20ASING.pdf

Http: / / www.mofa.go.jp/region/asia-paci/indonesia/epa0708 / agreement.pdf. Diakses 11/5/2011.

Http: / / pstalker.com/ilo/ resources/ Malaysia\%20Indonesia\%20

MOU\%20\&\%20Appendix\%20A-B.pdf. Diakses 17/5/2011.

Http: / / www.uncitral.org/pdf/english/texts/arbitration/NY-conv/ XXII_1_e.pdf

Http: / / www.unidroit.org/ english/ conventions / mobile-equipment/aircraftprotocol.pdf

Http: / / www.unidroit.org/ english/ conventions / mobile-equipment/mobile-equipment.pdf

Juwana, Hikmahanto. "Catatan atas Masalah Aktual dalam Perjanjian 
Internasional”. Jurnal Hukum Internasional, 5, 3 (2008): 443-451. Juwana, Hikmahanto. "Hukum Internasional Sebagai Instrumen Politik: Beberapa Pengalaman Indonesia Sebagai Studi Kasus.” Jurnal Hukum Internasional, 1, 1 (2003): 78-100.

Kusumaatmadja, Mochtar dan Etty R. Agoes. Pengantar Hukum Internasional. Bandung: PT. Alumni, 2003.

Shearer, I.A. Starke's International Law. United Kingdom: Butterworth \& Co. Ltd., edisi kesebelas, 1994.

\section{Peraturan Hukum}

Republik Indonesia. Undang-undang Nomor 24 Tahun 2000 tentang Perjanjian Internasional.

Republik Indonesia. Undang-undang Nomor 12 Tahun 2005 tentang

Pengesahan International Coventa on Civil and Political Rights

(Kovenan International tentang Hak-hak Sipil dan Politik).

Republik Indonesia. Undang-undang Nomor 1 Tahun 2009 tentang

Penerbangan.

Republik Indonesia. Undang-undang Nomor 47 Tahun 2007 tentang

Pengesahan Perjanjian antara Republic Indonesia dan Australia tentang Kerangka Kerja Sama Keamanan (Agreement between the Republic of Indonesia and Australia on the Framework for Security Cooperation).

Republik Indonesia. Undang-undang Nomor 5 Tahun 2009 tentang

Pengesahan United Nations Convention Against Transnational Organized Crime.

Republik Indonesia. Undang-undang Nomor UU Nomor 48 Tahun 2009 tentang Kekuasaan Kehakiman.

Republik Indonesia. Undang-undang Nomor 12 Tahun 2011 tentang

Pembentukan Peraturan Perundang-undangan.

Republik Indonesia. Peraturan Presiden Nomor 8 Tahun 2007 tentang

Pengesahan Convention on International Interests in Mobile

Equipment (Konvensi tentang Kepentingan Internasional dalam Peralatan Bergerak) Beserta Protocol to the Convention on International Interests in Mobile Equipment on Matters Specific to Aircraft Equipment (Protokol pada Konvensi tentang 
Kepentingan Internasional dalam Peralatan Bergerak Mengenai Masalah-Masalah Khusus pada Peralatan Pesawat Udara).

Republik Indonesia. Peraturan Presiden Nomor 36 Tahun 2008 tentang Pengesahan Agreement Between the Republic of Indonesia and Japan for An Economic Partnership (Persetujuan antara Republik Indonesia dan Jepang mengenai suatu Kemitraan Ekonomi).

Republik Indonesia. Keputusan Presiden Nomor 34 Tahun 1981 tentang Mengesahkan "Convention on the Recoginition and Enforcement of Foreign Arbitral Awards," yang telah ditandatangani di New York pada tanggal 10 Juni 1958 dan telah mulai berlaku pada tanggal 7 Juni 1959.

Republik Indonesia, Mahkamah Konstitusi. Putusan Nomor 13/ PUU-XVI/ 2018 dalam Perkara Pengujian UU Nomor 24 Tahun 2000 tentang Perjanjian Internasional terhadap UUD NRI Tahun 1945.

Republik Indonesia, Mahkamah Konstitusi. Putusan Nomor 33/ PUU-IX/2011 dalam Perkara Pengujian UU Nomor 38 Tahun 2008 tentang Pengesahan Charter of the Association of Southeast Asian Nations (Piagam Perhimpunan Bangsa-Bangsa Asia Tenggara) terhadap UUD NRI Tahun 1945.

The International Institute for the Unification of Private Law (UNIDROIT). Convention on International Interest in Mobile Equipment.

The International Institute for the Unification of Private Law (UNIDROIT). Protocol to the Convention on International Interests in Mobile Equipment on Matters Specific to Aircraft Equipment.

The International Monetery Fund dan Republik Indonesia. Letter of Intent of the Government of Indonesia to International Monetary Fund (October 31, 1997).

The United Nations. Convention against Torture and Other Cruel, Inhuman or Degrading Treatment or Punishment.

The United Nations Office for Disarmament Affairs (UNODA). Treaty on the Non-Proliferation of Nuclear Weapons, 1968. 
Hikmahanto Juwana

The World Trade Organization. Agreement Establishing the World Trade Organization. 